
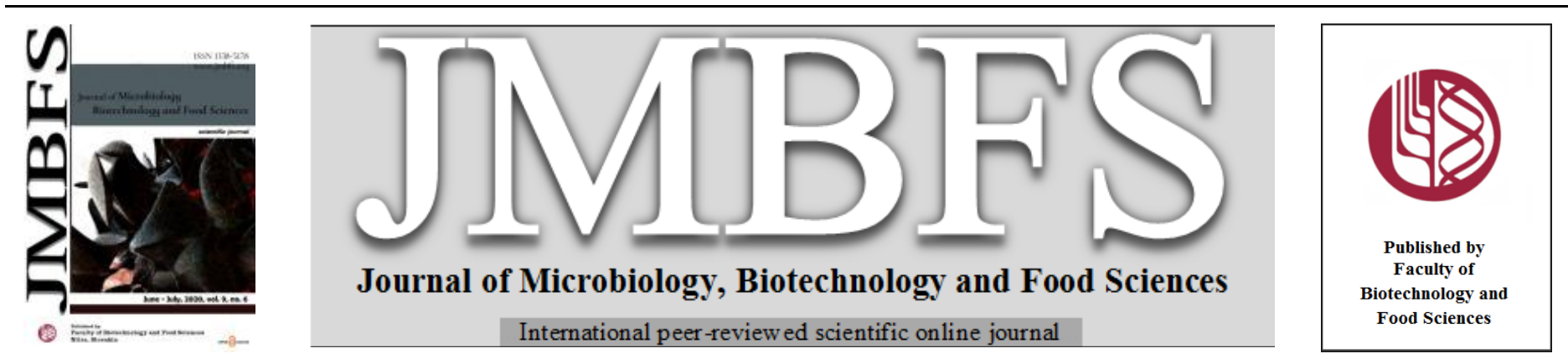

\title{
CONTAMINANT MICROBIOTA IN CRAFT BEERS
}

\author{
Marta García López ${ }^{a}$ Elena Roche ${ }^{b}$, Encarnación Rodríguez ${ }^{a}$
}

\begin{abstract}
Address(es):
${ }^{a}$ Department of Chemical \& Environmental Engineering, Universidad Politécnica de Madrid (UPM), c/ José Gutiérrez Abascal 2, 28006 Madrid, Spain.

${ }^{\mathrm{b}}$ Lecturer at the Escuela Superior de Cerveza y Malta. Universidad de Alcalá de Henares, c/ Avenida de las Américas, 4, nave CE, 28823 Coslada, Madrid., Spain.
\end{abstract}

*Corresponding author: eroche@etsii.upm.es

doi: 10.15414/jmbfs.2020.9.6.1181-1186

\section{ARTICLE INFO}

Received 18.9. 2019

Revised 17. 2. 2020

Accepted 18. 2. 2020

Published 1. 6. 2020

Regular article

OPEN $\partial_{\text {ACCESS }}$

\begin{abstract}
The microbiological stabilization treatment of beer sometimes guarantees the absence of microbiota. These treatments, however, are not usually done in craft beers. In this study, we have analyzed 38 craft beers from the Spanish market and found that, in $68 \%$ of cases, exogenous microbiota is present. The samples have been classified based on their alcohol content and the results have shown a large presence of wild yeasts in $100 \%$ of the contaminated beers with alcohol by volume (ABV) $<5 \%$. When the ABV $>6 \%$, the wild yeasts were only present in $41 \%$ of the samples; however, bacterial contaminants were detected in $50 \%$ of the samples. We also found that incorporating higher amounts of raw materials results in the presence of contaminant microbiota. These situations may be due to excessive manual operations, the lack of automation during cleaning and, above all, the absence of a stabilization treatment in the finished product.
\end{abstract}

Keywords: craft beers; wild yeasts; lactic acid bacteria; acetic acid bacteria; alcohol

\section{INTRODUCTION}

In the field of alcoholic beverages, beer has an important economic role with $78 \%$ of the world market share of alcoholic beverages (Gómez-Corona, et al., 2016a). In the last decade there has been a growing interest in craft beers, which have emerged as an alternative to industrially produced beers. These small factories are gaining a strong following due to the great interest that the consumer is showing for authentic flavors, finding in them a high-quality beer that offers a great variety of types and flavors.

In recent decades, the consumption of craft beer has increased worldwide. In the United States, since the mid-1980s, the number of craft breweries has increased exponentially, from 37 factories to 4225 in 2015 (Gatrell, et al., 2018, Craft Beer, 2017). This dizzying increase is starting to stabilize and consolidate. In Mexico and, in general, in Latin America, despite being an industrial beer market, small factories have burst into the market (Gómez - Corona, et al., 2016b). In Europe, the number of microbreweries has almost tripled, going from 3020 in 2011 to 7953 in 2017. Even though the United Kingdom, France and Germany are the countries that dominate the European market in this sector, with 2378, 1000 and 824 microbreweries respectively, in Spain there has been a $1000 \%$ increase between 2011 and 2017; in fact, the country ranked sixth in the number of factories in 2017 with 502 registered microbreweries, according to the statistical report prepared by The Brewers of Europe Association (2018).

In general, the term "craft brewery" applies to small, independent companies that use traditional production processes that emphasize quality, taste, and diversity, in addition to producing in limited quantities (Gatrell, et al., 2018), but there is no universal definition for "craft". In the United States, the Brewers Association has specific requirements that must be met to be included in its category of craft brewers, but the debate about the importance of size, ownership and ingredients continues (Euromonitor International, 2017). The situation is even less clear in other parts of the world, where there are no concrete parameters that define this sector. In Germany, in particular, the purity law of 1516 , or Reinheitsgebot (Kunzen, 2006), creates obstacles for those interested in participating in the art of making craft beer. In Spain, the regulation (BOE no. 304, 2016) includes the official definition of craft beer and reflects a manufacturing model where the human factor prevails over the mechanical factor, with the production of small lots in the same facility. All this is intended to avoid the incorporation of large brewers that, motivated by the entry into the market of new products, want to join the ranks of craft beer makers.

Beer as such is considered a safe food, from the point of view of food poisoning. According to a study (Suzuki, 2011) on the microbiological instability of beer caused by deteriorating bacteria, characteristics such as the presence of ethanol between $0.5-10 \%$ (mass/mass), bitter compounds of hops (between 17-55 ppm of iso- $\alpha$-acid), a high content of carbon dioxide (approximately $0.5 \%$ mass/volume), a low $\mathrm{pH}(3.8-4.7)$ and a reduced concentration of oxygen (generally less than 0.3 $\mathrm{ppm}$ ) make beer considered to be a microbiologically stable beverage and an inadequate medium for pathogenic microorganisms (Menz et al., 2010b). In addition to these intrinsic factors, many stages of the manufacturing process, such as maceration, boiling or filtration, limit microbiota growth. Additionally, final treatments such as pasteurization, amicrobic filtration, and aseptic packaging further reduce the potential for contamination (Menz et al., 2009).

Although beer does not develop microbiota that is problematic to health, there are certain microorganisms that can grow under these inhospitable conditions and alter its organoleptic properties. These are the so-called beer pollutants (Manzano et al, 2005), which include both bacteria and wild yeasts (Rainbow, C., 1981). Among the bacterial contaminants are, principally, the lactic acid bacteria (LAB) (Menz et al., 2010a), Acid-acetic bacteria (AAB) (Garofalo et al., 2015) and sometimes bacteria belonging to the enterobacteriaceae family (Menz et al, 2010a). Others microorganism can produce significant deterioration in the organoleptic profile of beer how Pectinatus y Megasphaera (Paradh et al, 2011; Sakamoto et al., 2003).

The presence of all these microorganisms has been related to the organoleptic or colloidal stability of beer. Characteristics such as changes in acidity, the presence of abnormal aromas and undesirable tastes, turbidity, etc., are parameters that notably deteriorate any beer (Manzano et al., 2005). For all these reasons, the microorganisms that damage this drink are a serious problem for its commercialization since they deteriorate the product and, in doing so, they can damage the value of the brand, damage that is sometimes difficult to repair.

Therefore, the brewing industry strives to avoid the presence of contaminating microorganisms so as to offer a product that is biologically stable until its expiration date. However, in craft beers it is rare to subject the production to microbiological stabilization treatments such as pasteurization, aseptic packaging or sterile filtration.

When making craft beer, the producer designs a recipe that sometimes strays from basic brewing procedures to ensure that its product is a unique and exclusive drink. As a result, the variability of the ingredients is enormous, as are the possibilities of using the same component in different forms and in different stages of the process. In addition, craft breweries are usually small- and mediumsized facilities, with little automation where manual operations prevail, with few workers who, on occasion, must cover a multitude of functions that are very different from one another. This beer is usually commercialized without any type of treatment to guarantee the elimination of microorganisms that alter the 
finished product. Therefore, these types of beers are more susceptible to the deterioration from microbial contaminants.

Raw materials such as hops, and fermentation products such as ethanol are natural microbial inhibitors in any beer. The most notable example of this antiseptic capacity are the famous IPA (Indian Pale Ale) beers, where the high contents of both the added hops and the alcohol produced ensure the preservation of the product during its long transport by sea, originally from England to India (Serra Colomer et al, 2018). Therefore, hops are traditionally used, not only for their ability to give that characteristic flavor, but for their outstanding antimicrobial and antioxidant properties

On the other hand, ethanol is an inhibitor of microbial growth because it also acts at the level of the cell membrane, causing irreparable damage. Gram-positive bacteria, in general, have a high sensitivity to alcohol except LAB, which have a high tolerance to high levels of this compound (Coda et al., 2011, Kramer et al., 2015). In contrast, within the Gram-negative flora, an average ethanol content > $3.5 \%(\mathrm{v} / \mathrm{v})$ affects the development of microorganisms such as Megaspharea and Pectinatus (Suzuki et al., 2008). As for the yeasts, alcohol has a greater inhibitory effect than the components of hops, both for the culture and wild yeasts (Michel et al., 2016, Manzano et al., 2011).

An interesting aspect is the great biodiversity of microbiota that may be presen in craft beers. The cause may be the complexity of the environment in the microbreweries themselves, together with the infinite variety of ingredients that become part, as possible starter cultures, in the processes of alcoholic fermentation (Cocolin, et al., 2011). Another cause might be the use of different strains of yeast, other than Saccharomyces, to obtain innovative or nove products, such as current sour-type beers, or the manufacture of fermented beers with a low alcohol content, or even the production of beers with a marked volatile fraction (Basso et al., 2016; Serra Colomer, et al., 2018), or the possibility of maintaining a mixed flora with prebiotic yeasts, thus giving a greater added value to the product (Capece et al., 2018; Romano et al., 2017).

Thus, under scenario, the objective of this study was to investigate the frequency with which polluting flora appear in commercial craft beers purchased in the market.

\section{MATERIAL AND METHODS}

\section{Beer samples}

Thirty-eight commercial craft beers from 25 Spanish microbreweries were studied. Table 1 shows the craft beers that complied with current Spanish law (BOE no. 304 of 2016). All the craft beers were packaged in $330 \mathrm{~mL}$ glass bottles.

The samples were numbered and ordered according to the alcohol content, which was on the label. The label also indicated the type of beer and its ingredients.

Table 1 Craft beers analyzed the beer type information.

\begin{tabular}{|c|c|c|c|}
\hline CRAFT BEER & STYLE & ALCOHOL \% (V/V) & INGREDIENTS \\
\hline 1 & ALE & 2,6 & WATER, BARLEY MALT, OATS, HOP AND YEAST \\
\hline 2 & PALE ALE & 3,6 & WATER, BARLEY MALT, HOP AND YEAST \\
\hline 3 & BLONDE & 4,5 & WATER, BARLEY MALT, HOP AND YEAST \\
\hline 4 & BLONDE & 4,5 & WATER, BARLEY MALT, HOP AND YEAST \\
\hline 5 & ALE & 4,5 & WATER, BARLEY MALT, PASSION FRUIT, HOP AND YEAST \\
\hline 6 & ALE & 4,8 & WATER, BARLEY MALT, HOP AND YEAST \\
\hline 7 & WHEAT & 4,8 & WATER,WHEAT MALT, BARLEY MALT, HOP AND YEAST \\
\hline 8 & ALE BELGA & 4,9 & WATER, BARLEY MALT, HOP AND YEAST \\
\hline 9 & BLONDE & 5 & WATER, BARLEY MALT, HOP AND YEAST \\
\hline 10 & BLONDE & 5 & WATER, BARLEY MALT, HOP AND YEAST \\
\hline 11 & IPA & 5 & WATER, BARLEY MALT, HOP AND YEAST \\
\hline 12 & WHEAT & 5 & WATER,WHEAT MALT, BARLEY MALT, HOP AND YEAST \\
\hline 13 & PALE ALE & 5 & WATER, BARLEY MALT, HOP AND YEAST \\
\hline 14 & TRIGO & 5,1 & $\begin{array}{l}\text { WATER, WHEAT MALT, BARLEY MALT, HOP, YEAST, CORIANDER, BITTER } \\
\text { ORANGE, ROSES, CARROT AND SEAWATER }\end{array}$ \\
\hline 15 & WHEAT & 5,1 & $\begin{array}{l}\text { WATER, WHEAT MALT, BARLEY MALT, HOP, YEAST, CORIANDER, } \\
\text { BITTER ORANGE AND SEAWATER }\end{array}$ \\
\hline 17 & ALE & 5,2 & WATER, BARLEY MALT, HOP AND YEAST \\
\hline 18 & PALE LAGER & 5,2 & WATER, BARLEY MALT, HOP AND YEAST \\
\hline 19 & DRY STOUT & 5,2 & WATER, BARLEY MALT, HOP, YEAST AND COFFEE \\
\hline 20 & PALE ALE & 5,5 & WATER, BARLEY MALT, HOP AND YEAST \\
\hline 22 & PALE ALE & 5,5 & WATER, BARLEY MALT, HOP AND YEAST \\
\hline 23 & PALE ALE & 5,5 & WATER, BARLEY MALT, HOP AND YEAST \\
\hline 21 & PALE ALE & 5,5 & WATER, BARLEY MALT, HOP AND YEAST \\
\hline 24 & ALE & 5,5 & WATER,WHEAT MALT, BARLEY MALT, HOP AND YEAST \\
\hline 25 & PALE ALE & 5,5 & WATER, BARLEY MALT, HOP AND YEAST \\
\hline 26 & IPA LAGER & 5,8 & WATER, WHEAT MALT, HOP, YEAST AND RED FRUITS \\
\hline 27 & BITTER & 6,2 & WATER, BARLEY MALT, HOP AND YEAST \\
\hline 28 & $\begin{array}{l}\text { BELGIAN } \\
\text { ABBEY }\end{array}$ & 6,3 & WATER, BARLEY MALT, OATS, HOP AND YEAST \\
\hline 29 & IPA & 6,4 & WATER, BARLEY MALT, HOP AND YEAST \\
\hline 30 & $\begin{array}{l}\text { BELGIAN } \\
\text { DUBBEL }\end{array}$ & 6,5 & WATER, BARLEY MALT, HOP, YEAST AND SPICES \\
\hline 31 & NEGRA & 6,5 & WATER,WHEAT MALT, BARLEY MALT, HOP AND YEAST \\
\hline 34 & IMPERIAL IPA & 8 & WATER, BARLEY MALT, SUGARCANE, MUSTARD SEEDS, HOP AND YEAST \\
\hline 35 & $\begin{array}{l}\text { COFFEE } \\
\text { STOUT }\end{array}$ & 8 & WATER, BARLEY MALT, HOP, YEAST AND COFFEE \\
\hline 36 & $\begin{array}{l}\text { IMPERIAL } \\
\text { STOUT }\end{array}$ & 8,1 & WATER, BARLEY MALT, HOP, YEAST AND VANILLA \\
\hline 37 & ALE & 8,9 & WATER, BARLEY MALT, WHISKY, HOP AND YEAST \\
\hline 38 & $\begin{array}{l}\text { BELGIAN } \\
\text { QUADRUPEL }\end{array}$ & 11,1 & WATER, BARLEY MALT, HOP, YEAST AND RED KAMPOT PEPPER \\
\hline
\end{tabular}

\section{Culture media}

The microbiological analysis was conducted according to the procedures contained in Section 4.0 of the European Brewery Convention-Analytica Microbiologica (EBC, 2005) for detecting contaminants in beer. To detect total mesophilic flora, the WLN (Wallerstein Laboratory Nutritive Agar (4.3.2.1)) and Agar Mosto (4.3.2.1) were used as a means of general counting. For aerobic bacteria, WLD (Wallerstein Laboratory Differential Agar (4.2.4.3a)) was used with cycloheximide to inhibit yeast growth

To determine the presence of wild yeasts, Lysine Agar (4.2.6) was used since the presence of lysine favors the development of wild yeasts that do not belong to the Saccharomyces genus. Also MYGP was used, a medium with malt extract, yeas extract, glucose and peptone, with $\mathrm{CuSO} 4$ (4.2.5.1), since the presence of $\mathrm{Cu}$ inhibits the growth of culture yeasts and thus allows the growth of wild yeasts, including Saccharomyces (Kühle, et al., 1998). 
To isolate LAB Gram-positive bacteria, we worked with mMRS (Manosa Rogosa), Sharpe Agar (4.3.3.1) and Raka Ray, selective media for isolating lactic acid bacteria from the brewing process. To avoid yeast growth, $10 \mathrm{ml} / \mathrm{L}$ of a sterile $0.1 \%$ cycloheximide solution was added to these media, and to inhibit the growth of Gram-negative bacteria, we used $0.2 \%(\mathrm{v} / \mathrm{v})$ of $\beta$-phenylethanol (4.3.3.1).

In the case of Gram-negative flora, for the acetic acid bacteria (AAB) the Willianson (Suarez, et al., 2004) medium was used as a general means of acetic bacteri, and the Carr Agar (4.2.4.3) medium was used to differentiate the most common AAB genera in breweries: Gluconobacter and Acetobacter. For enterobacteria, Mc Conkey (4.1.3.1) was the chosen medium, since the presence of bile salts and violet crystal inhibited Gram-positive bacteria, and lactose was used as the sole source of sugar.

All culture media were prepared in the laboratory, sterilized in an autoclave and distributed on a plate under sterile conditions in a laminar flow hood.

\section{Sample preparation, inoculation and plate reading}

The craft beers were kept in adequate hygienic conditions, at a constant temperature of $20^{\circ} \mathrm{C}$, humidity of $42 \%$ and in darkness. Prior to the analysis, the beers were cooled to a temperature of $4-5{ }^{\circ} \mathrm{C}$ and sprayed with alcohol and flamed before opening. All determinations were performed under sterile conditions in a vertical laminar flow hood (TeLstar AV30/70).

To sow the beers, direct sowing was used on the culture medium, as per the procedures contained in European Brewery Convention-Analytica Microbiologica, section 2.0 (EBC, 2005). Seeding was carried out on the surface or by flooding (2.3.3.2.) of $0.2 \mathrm{~mL}$ per sample plate, all in triplicate. To achieve a more homogeneous sample, the beer was transferred to a sterile $100-\mathrm{mL}$ container, which also facilitated the taking of samples and avoided excessive frothing of the beer.

The other seeding technique was membrane filtration, as per the procedures contained in European Brewery Convention-Analytica Microbiologica, section 2.0 (EBC, 2005). To ensure that the microorganisms were retained on the surface of the membrane, a Microkit filtration system from MILLIPORE, connected to a Millivac vacuum pump, was used. The membranes used were nitrocellulose with a pore diameter of 0.45 microns, and $100-\mathrm{mL}$ sterile, single-use funnels. With this technique, the filtered dose was $2 \mathrm{~mL}$ and to ensure the correct distribution of the sample over the entire surface of the membrane, $10 \mathrm{~mL}$ of sterile water were added beforehand. After the filtration, the membrane was deposited in the different culture media described above. As in the previous plantings, filtrations were carried out in triplicate and in a laminar flow hood under sterile conditions. The planted culture media were incubated at controlled temperature and atmosphere. Incubation is the period of growth necessary for a single cell to pas into a visible colony. The aerobic incubation, in atmospheric air, was used for general counting media (mWLN), aerobic bacteria count (mWLD), yeast (Mosto agar) and acetic bacteria. For anaerobic microorganisms, MRS and RR media were used for lactic acid and MacConkey bacteria for enterobacteria, which were incubated with a carbon catalyst EZ Gas Pack (Anaerobe Pouch System of BC) with an anaerobic indicator to remove all oxygen.

All the samples seeded in the culture media were incubated at a temperature of 28 ${ }^{\circ} \mathrm{C}+/-1{ }^{\circ} \mathrm{C}$ for 5 days, with a first reading at $72 \mathrm{~h}$, with the exception of the agar plates, which in addition to being incubated at that temperature, were also incubated for the same period in an oven at $37^{\circ} \mathrm{C}$.

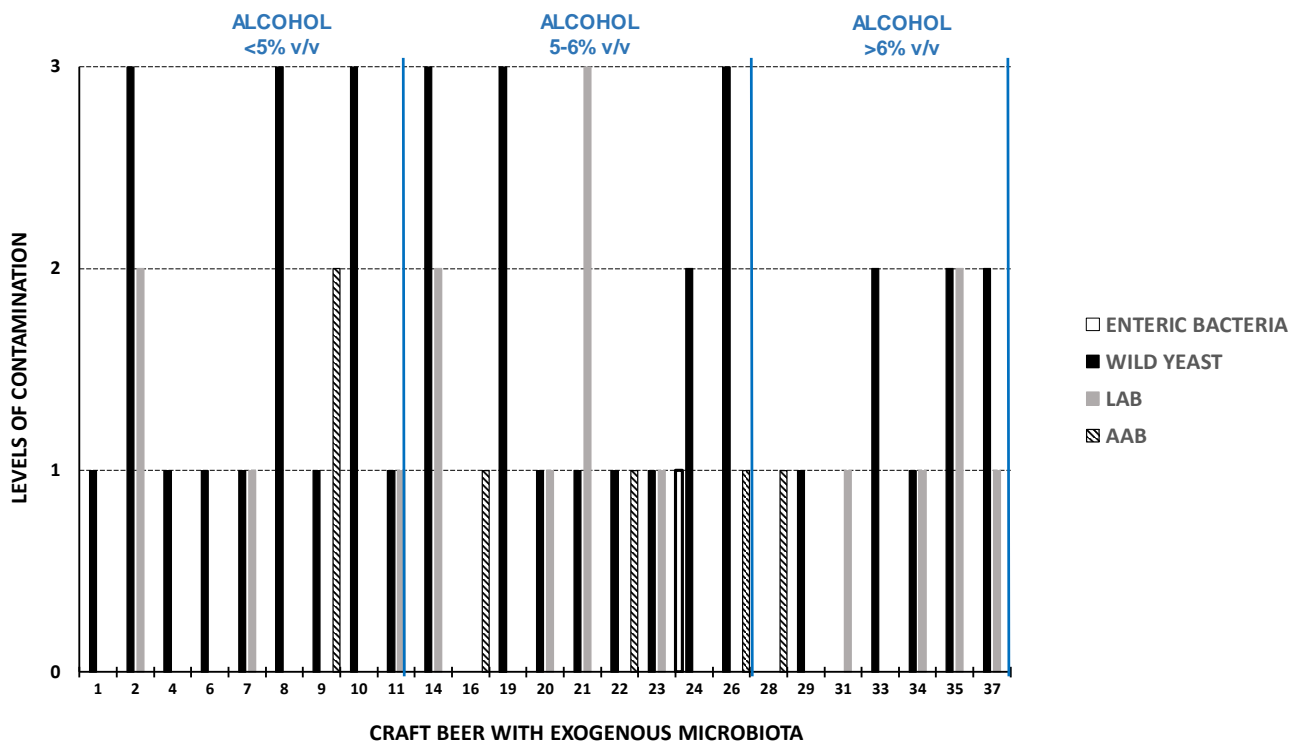

Figure 1 Alcohol content in $\%(\mathrm{~V} / \mathrm{V})$ and level of contamination only in craft beers samples with presence exogenous microbiota Level 0: not detected/absence; Level 1: 0-50 CFU/mL; Level 2: 50-100 CFU/mL; Level 3:> 100 CFU/mL).
At the end of the incubation, the results of the plates were recorded by direct visual examination and by observation with a magnifying glass. With all colonies detected, a fresh, microscopic examination was carried out, that is, direct examination to distinguish between yeasts and bacteria, as per the procedures contained in European Brewery Convention-Analytica Microbiologica, section 2.0 (2.3.5) (EBC, 2005). Those identified as bacteria underwent differential Gram staining and/or differentiation with a $2 \% \mathrm{~m} / \mathrm{v}$ (mass/volume) potassium hydroxide solution, as per the procedures contained in European Brewery Convention Analytica Microbiologica, section 2.0 (2.3.6) (EBC, 2005). Once the morphology of the microorganism and the type of wall were identified, the catalase activity test (2.3.7) was carried out (EBC, 2005) with a $3 \% \mathrm{~V} / \mathrm{V}$ hydrogen peroxide solution. In Gram-negative bacteria and positive catalase, the oxidase test was performed since the cytochrome system is normally present only in aerobic organisms capable of using oxygen as the final hydrogen acceptor (Isenberg, 2004)

Contamination levels were assessed semi-quantitatively and grouped into three levels, according to the number of bacterial colony forming units (CFU) and taking as reference the study (Menz, 2010a) on the isolation, identification and characterization of $\mathrm{LAB}$ in craft beer. Beers between $0-50 \mathrm{CFU} / \mathrm{mL}$ were considered as having a "low" level of contamination, or Level 1; beers with counts between 50-100 CFU/mL as "medium", or Level 2; and a "high" level of contamination, or Level 3, was defined when the number of isolated microorganisms exceeded $100 \mathrm{CFU} / \mathrm{mL}$. When no microbiological growth was detected on the plates, the term "absent", or level 0 of contamination, was assigned.

\section{Physicochemical Analysis}

In order to obtain information about the final compounds present in the beer and analyze their influence on the microbiota found, physical-chemical analyses were carried out on twelve craft beers from the same producer. These analyses were carried out using the official methodology indicated in section 9 of the Analytica European Brewery Convection (EBC, 2007). The parameters analyzed were: real and apparent original extract (9.4); alcohol (9.2.1); actual degree of fermentation (9.5); color (9.6); $\mathrm{pH}$ (9.35); free amino nitrogen (9.10); total polyphenols (9.11) and bitter (9.8)

\section{RESULTS AND DISCUSSION}

\section{Influence of alcohol on the contaminated microbiota}

Figure 1 shows the alcohol content $\%(\mathrm{v} / \mathrm{v})$ and the results of microbiological contamination levels of wild yeasts, lactic acid bacteria (LAB), acetic bacteria $(\mathrm{AAB})$ and enteric microbiota obtained from the analysis of the craft beers studied.

As the figure shows, $68 \%$ of the samples (26 cases) had contaminating microbiota. In these contaminated beers, the flora present were bacteria and wild yeasts, in $37 \%$ of the cases. In turn, in $21 \%$ of the samples, only wild yeasts were isolated, and only bacterial growths were observed in $10 \%$ of the remaining cases 
Additionally, a different microbiota distribution was observed based on the alcohol content. Thus, for beers with a content $<5 \%(\mathrm{v} / \mathrm{v})$, a greater presence of wild yeasts was observed compared to the bacterial flora. In beers with alcohol content between $5-6 \%(\mathrm{v} / \mathrm{v})$, all the samples were contaminated with both wild yeasts and bacteria, while in beers with a content $>6 \%(\mathrm{v} / \mathrm{v})$, a greater presence of bacteria with respect to yeasts was observed.

Relating the growth of wild yeast with the concentration of alcohol, it was observed that, as the beers' alcohol content increased, the presence of wild yeasts decreased, although this did not always happen. Such is the case of Brettanomyces, a wild yeast that is capable of withstanding an alcohol content of up to $15 \%$ (v/v) (Serra Colome, et al., 2018). The results would indicate that many of the wild yeasts had a low tolerance to alcohol, as is the case with culture yeasts. Therefore, an alcohol concentration $>6 \%(\mathrm{v} / \mathrm{v})$ was inhibitor.

However, it was observed that by increasing the alcohol content, the growth of bacteria was not inhibited, so no relationship could be established between the alcohol content and the presence of contaminating bacteria. Of the three groups of bacteria analyzed, contamination by LAB flora was the most frequent and coincides with another study (Menz et al., 2010a) that justifies its presence because beer turns out to be an optimal substrate for the development of Grampositive bacilli and cocci and catalase negative bacteria, so they could be Lactobacillus and Pediococcus. In 11 of the 38 beers analyzed, the presence of LAB was detected. Relating these beers contaminated by bacteria with their alcoholic content, the group of low-grade beers $(<5 \%(\mathrm{v} / \mathrm{v}))$ did not exhibit more contamination than the other two groups, despite being more vulnerable to attack by external microbial agents, and there was only one case where the amount of these microorganisms reached a higher level (level 3). In general, the presence of bacteria in beers was detected at medium-low levels (Vriesekoop, et al., 2013).

The AAB microorganisms were detected in 5 of the 38 beers analyzed and it was not possible to relate the presence of these Gram-negative, catalase positive or oxidase negative bacteria with the alcohol content, since the results were level 1 throughout the range of alcohol content ( 2.8 to $11 \%(\mathrm{v} / \mathrm{v}))$. Acetic bacteria are, in general, strict aerobic microorganisms that need high levels of oxygen to survive, so most of the incidences related to these germs are associated with the entry of oxygen in the packaging phases (Vriesekoop et al., 2013). To increase the amount of carbon in bottled beer, many of the breweries add sugars to the bottle itself and there is evidence (Dolezil, L. et al., 1980) that secondary fermentation in the container itself reduces the susceptibility of this beverage to microbial attack by aerobic bacteria, since the leavening in fermentation reduces the oxygen content that could remain after packaging.

In the case of Enterobacteria, its presence was only detected in one sample at contamination level 1 , so it was not possible to determine the influence of alcohol on this important group of bacteria. These microorganisms are not common in bottled beers (Menz et al, 2010b, Spitaels et al., 2015, Vriesekoop, et al., 2013)

\section{Influence of the manufacturing lot on the contaminated flora}

Figure 2 shows the results of beer samples 20, 21 and 22, corresponding to a pale ale beer from the same manufacturer, but produced in consecutive manufacturing batches. The microbiological results of the three samples indicate contamination by both wild yeasts and bacteria. In the case of wild yeasts, these appeared in all three lots and always at a low level of contamination (level 1), but the presence of bacteria increased exponentially and alarmingly. Sample 20 showed a low level of contamination (level 1), while in the other two (samples 21 and 22) it reached a high contamination level (level 3). In addition, in the third batch, the presence of another group of bacteria, $\mathrm{AAB}$, was detected, which is why these data make us suspect low or inadequate sanitation of the facilities, which would cause the microbiological contamination to increase (Menz, et al., 2010a).

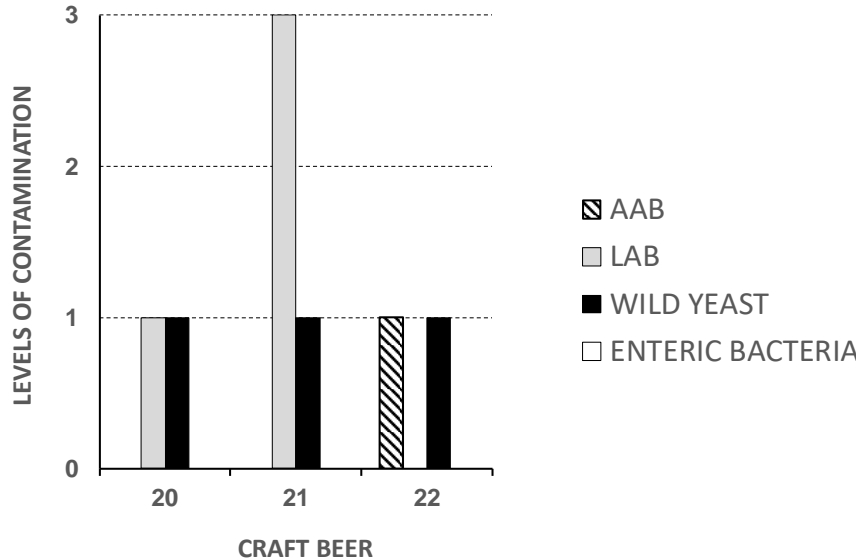

Figure 2 Level of microbial contamination in craft beer the same manufacturer and different manufacturing batches

Level 0: not detected/absence; Level 1: 0-50 CFU/mL; Level 2: 50-100 CFU/mL; Level 3:> $100 \mathrm{CFU} / \mathrm{mL}$ ).

\section{Influence of raw materials on the contaminated microbiota}

At the industrial level, beers are usually classified based on the amount of extract used in their preparation or on the production method that is associated with the use of unmodified processing ingredients. In craft beers there is greater freedom in the use of different manufacturing methods and ingredients, thereby yielding autonomous and specific styles for each producer. In addition, as they strike for exclusivity in their products, artisan brewers must look for different ingredients and introduce them at different points of the process. As a result, as the study by Vaughan A. et al. (2005) shows, the microbiota of the product can come both from a secondary contamination of the facilities and from a primary contamination of the raw materials.

Table 2 shows the results of the level of microbiological contamination detected and the values determined for several physical-chemical parameters in 12 beers from the same manufacturer. In these beers, the influence of raw materials on the development of microbial flora was studied. Seven of the samples analyzed contained ingredients in addition to the basic ones (water, barley malt, hops and yeast).

Table 2 Influence of exogenous microbiota in craft beer the same manufacturer with different raw materials

\begin{tabular}{|c|c|c|c|c|c|c|c|c|c|c|c|c|}
\hline & \multicolumn{12}{|c|}{ CRAFT BEI } \\
\hline & $\mathbf{1}$ & $\mathbf{1 3}$ & 18 & 19 & 32 & 5 & 14 & 15 & 26 & 36 & 37 & 38 \\
\hline \multicolumn{13}{|l|}{ ANALYSIS PHYSIOCHEMICAL } \\
\hline ALCOHOL (\% v/v) & 2,7 & 5 & 4,5 & 5,3 & 6,6 & 4,8 & 4,5 & 4,5 & 5,3 & 7,6 & 8,4 & 9,9 \\
\hline APPARENT EXTRACT (\%) & 2,0 & 3,4 & 2,8 & 3,5 & 4,0 & 2,9 & 3,0 & 3,1 & 3,3 & 4,8 & 5,3 & 1,3 \\
\hline REAL EXTRACT (\%) & 3,2 & 5,3 & 4,6 & 5,3 & 6,2 & 4,9 & 4,7 & 4,5 & 5,3 & 7,9 & 7,8 & 5,3 \\
\hline ORIGINAL EXTRACT (\%) & 7,3 & 13,2 & 11,6 & 13,0 & 16,2 & 12,0 & 11,7 & 11,5 & 13,0 & 19,2 & 19,4 & 21,8 \\
\hline REAL DEGREE FERMENTATION (\%) & 57,9 & 61,6 & 61,9 & 61,0 & 63,9 & 61,1 & 61,5 & 62,1 & 61,0 & 61,6 & 62,1 & 77,9 \\
\hline ENERGETIC VALUE (kcal/100mL) & 33,2 & 49,9 & 45,2 & 49,2 & 59,6 & 46,5 & 45,6 & 45,4 & 49,2 & 67,6 & 68,2 & 84,9 \\
\hline TOTAL POLYPHENOLS (mg/L) & 110 & 328 & 274 & 308 & 330 & 216 & 254 & 205 & 267 & 554 & 385 & 402 \\
\hline FREE AMINO NITROGEN (mg/L) & 30 & 109 & 100 & 48 & 94 & 75 & 60 & 86 & 108 & 98 & 212 & 110 \\
\hline BITTERNESS (BU) & 18 & 22 & 26 & 33 & 25 & 34 & 18 & 27 & 52 & 64 & 26 & 27 \\
\hline COLOUR (u EBC) & 13 & 67 & 15 & 102 & 35 & 15 & 17 & 15 & 24 & 96 & 96 & 92 \\
\hline $\mathrm{pH}$ & 4,6 & 4,5 & 4,7 & 4,4 & 4,5 & 4,0 & 4,4 & 4,5 & 4,5 & 4,6 & 4,5 & 4,4 \\
\hline \multicolumn{13}{|l|}{ LEVELS OF CONTAMINATION } \\
\hline WILD YEAST & 1 & 0 & 0 & 3 & 0 & 0 & 3 & 0 & 3 & 0 & 2 & 0 \\
\hline LAB & 0 & 0 & 0 & 0 & 0 & 0 & 2 & 0 & 0 & 1 & 1 & 0 \\
\hline $\mathrm{AAB}$ & 0 & 0 & 0 & 0 & 0 & 0 & 0 & 0 & 1 & 0 & 0 & 0 \\
\hline ENTEROBACTERIAS & 0 & 0 & 0 & 0 & 0 & 0 & 0 & 0 & 0 & 0 & 0 & 0 \\
\hline
\end{tabular}

In the microbiological analyses of these 12 beers, it was observed that $30 \%$ of the samples had some kind of contamination - wild yeasts, bacteria or both types of microorganisms. By relating the presence of the exogenous microbiota with the types of ingredients, we found that when the beers were made only with basic manufacturing ingredients, there was contamination by wild yeast (two samples).
In one of the samples (\#1), the contamination level was low (level 1). In the other (sample \#19), the level was high (level 3). In sample \#1, the analysis of bitters from hops was only $18 \mathrm{BU}$ and the alcohol content was the lowest in the whole group. However, in sample \#19, where the wild yeasts reached contamination level 3, the contents of bitters and alcohol were practically doubled. 
Consequently, both parameters, bitterness of hops and alcohol, described as factors that inhibit the growth of microorganisms (9), did not seem to act, in this case, as inhibitors of the development of yeasts. It is possible to associate their presence with the amount of real extract and residual FAN (Free Amino Nitrogen), which allow yeasts to find nutrients for their development ((Menz et al., 2010a).

All the beers studied were in a $\mathrm{pH}$ range of 4.40 - 4.70 except sample \#5, whose value was 4.00 . Regarding the presence of microorganisms, no influence could be established between the amounts or type of contaminant and the $\mathrm{pH}$ value since variations in the $\mathrm{pH}$ range from one sample to another were very small. Menz et al. (2010a), in their work on Australian craft beers, determined that beer pollutants are, in general, tolerant to the presence of ethanol when the $\mathrm{pH}$ values are higher than 4.06. Specifically, in beer \#5 with an alcoholic content of $4.8 \%$ $(\mathrm{v} / \mathrm{v})$ and a $\mathrm{pH}$ of 4.0 , the presence of exogenous microbiota was zero.

As for those beers that contained other ingredients besides the basic ones, it was found that four out of seven samples showed exogenous microbial contamination (beers \#14, \#26, \#36 and \#37). The distribution of the microbiota found again indicated that in the two samples with higher alcohol content $(>6.5(\mathrm{v} / \mathrm{v}))$, one had a low level (level 1) of bacterial contamination and no wild yeasts, and in the other, a level 2 of wild yeast and level 1 of bacteria was detected. In contrast, in the other two samples (\#14 and \#26) whose alcohol content was lower (4.5 $5.3 \% \mathrm{~V} / \mathrm{V}$ - volume/volume), wild yeast (level 3) and bacteria were isolated (Level 2). The physical-chemical analyses again confirmed that the beer with the highest alcohol content (\#37), where the real extract and FAN were high, CONTAINED remains of sugars that are not fermentable by the yeast but that could perhaps be used by other flora (Serra et al., 2018). Therefore, with the data obtained, it seems that the presence of contaminants is more associated with beers in particular, rather than with the intrinsic antimicrobial obstacles typical of beer, as Menz, G., et al. (2010a) showed in their study of craft beers in Australia Our results indicate that when beers are made with basic ingredients such as water, malt, hops and yeast, microbial contamination is associated with wild yeast. However, in cases where some additional ingredients are included, such as vanilla, bitter orange, roses, carrots, cilantro and red berries, microbial contamination is associated with bacteria.

\section{CONCLUSIONS}

The microbiota contaminants in crafts beers analyzed consisted mainly of wild yeasts and lactic bacteria and, occasionally, acetic bacteria. In this study, we have shown that the natural intrinsic characteristics of beer, such as alcohol content, $\mathrm{pH}$ or the presence of bitter hop substances, are unable to inhibit the growth of contaminating microorganisms. This is evidenced by the fact that $37 \%$ of the beers analyzed were contaminated by both bacteria and wild yeasts, $21 \%$ of the samples analyzed were contaminated by wild yeasts, and only bacteria were detected in $10 \%$ of the samples.

The influence of the alcohol content on the distribution and level of contamination showed that when the alcohol content was low $(<5 \%(\mathrm{v} / \mathrm{v}))$, wild yeasts appeared in $100 \%$ of the contaminated samples-and in bacteria $30 \%$. When the alcohol content of the beer was $>6 \%(\mathrm{v} / \mathrm{v})$, contamination with wild yeasts was reduced to $41 \%$ of the cases, while the presence of bacteria increased in up to $50 \%$ of the samples. It was not possible to establish a clear correlation between the bitterness of the beer coming from the hops and the microbial contamination. However, we found that the content of unfermented residues (real extract and FAN) influences the development of the contaminating microbiota. In addition, we found that $71.4 \%$ of beers that contained ingredients other than the basic ones (water, barley malt, hops and yeast) had microbial contamination.

The manufacturing method, including a secondary fermentation in the bottle, the performance of manual operations in the facilities, the lack of automation when cleaning and, above all, the absence of a stabilization treatment of the finished product, can be factors that facilitate the survival of contaminating microorganisms and, therefore, their presence in the finished product.

\section{REFERENCES}

Basso, R.F., Alcarde A.R. \& Portugal, C.B., (2016). Could non-Saccharomyces yeasts contribute on innovative brewing fermentations? Food Res. Int. 86, 112 120. http://dx.doi.org/10.1016/j.foodres.2016.06.002

BOE 304/2016. Real Decreto 678/2016, de 16 de diciembre, por el que se aprueba la norma de calidad de la cerveza y de las bebidas de malta. pp. $88520-$ 88524. https://www.boe.es/eli/es/rd/2016/12/16/678

Capece, A., Romaniello, R., Pietrafesa, A., Siesto, G., Pietrafesa, R., Zambuto,M \& Romano, P. (2018). Use of Saccharomyces cerevisiae var. boulardii in cofermentations with $\mathrm{S}$. cerevisiae for the production of craft beers with potential healthy value added. Int. J. Food Microbiol. 284 ,22-30. https://doi.org/10.1016/j.ijfoodmicro.2018.06.028

Cocolin, L., Campolongo, S., Gorra, R., Rolle, L. \& Rantsiou, K. (2011). Saccharomyces cerevisiae biodiversity during the brewing process of an artisanal beer: A preliminary study. J. Inst. Brew. 117, 352-358. https://doi.org/10.1002/j.2050-0416.2011.tb00479.x
Coda, R., Rizzello, C.G., Trani, A. \& Gobbetti, M. (2011). Manufacture and characterization of functional emmer beverages fermented by selected lactic acid $\begin{array}{llllll}\text { bacteria. } & \text { Food } & \text { Microbiol. } & 28, & 526 & -\end{array}$ https://doi.org/10.1016/j.fm.2010.11.001

Craft Beer in 2017. Brewers Association Releases Midyear Report. Baker, J. https://www.craftbeer.com/editors-picks/craft-beer-midyear-report-2017

Dolezil, L. and Kirsop, B. H. (1980) Variations amongst beers and lactic acid bacteria relating to beer spoilage. J. Inst. Brew. 86, 122-124 https://doi.org/10.1002/j.2050-0416.1980.tb03969.x

Euromonitor International (2017). Competitive Strategies in Alcoholic Drinks. https://www.euromonitor.com/competitive-strategies-in-alcoholic-drinks

European Brewery Convention (2005). Analytica-Microbiologica-EBC (2sd ed.). Nürnberg: Fachverlag Hans Carl. (https://europeanbreweryconvention.eu)

European Brewery Convention (2007). Analytica-EBC $\left(5^{\text {th }}\right.$ ed.). Nürnberg: Fachverlag Hans Carl. (https://europeanbreweryconvention.eu)

Garofalo, C., Osimani, A., Milanovic, V., Taccari, M., Aquilanti, L. \& Clementi, F. (2015). The occurrence of spoilage lactic acid bacteria in craft beer production. J. Food Sci. 80, 2845-2853.https://doi.org/10.1111/1750-3841.13112

Gatrell. 2018. Branding spaces: Place, region, sustainability and the American craft beer industry. Appl. Geogr. 90, 360-370 https://doi.org/10.1016/j.apgeog.2017.02.012

Gómez-Corona, C., Lelievre-Desmas, M., Escalona H.B., Chollet, S. \& Valentin, D. (2016a). Craft beer representation amongst men in two different cultures. Food Qual. Prefer. 53, 19-28. https://prodinra.inra.fr/record/372578

Gómez-Corona, C., Escalona H.B., García, M., Chollet, S. \& Valentin, D. (2016b). Craft vs. Industrial: habits, acttitudes and motivations towards beer $\begin{array}{lll}\text { consumption in } & \text { Mexico. } & \text { 358-367. }\end{array}$ https://doi.org/10.1016/j.appet.2015.10.002

Isenberg. HD (2004) Clinical Microbiology Procedures Handbook, second ed. American Society for Microbiology Press. https://doi.org/10.1016/j.diagmicrobio.2004.11.003

Kramer, B., Thielmann, J., Hickisch, A., Muranyi, P., Wunderlich, J. \& Hauser, C. (2015). Antimicrobial activity of hop extracts against foodborne pathogens for meat applications. J. Appl. Microbiol. 118, 648-657. https://doi.org/10.1016/i.diagmicrobio.2004.11.003

Kühle, A. \& Jespersen, L. (1998). Detection and identification of wild yeasts in lager breweries. Int. J. Food Microbiol. 43, 205-213 https://doi.org/10.1016/S0168-1605(98)00113-5

Kunze, W. (2006). Tecnología para cerveceros y malteros, First ed. VLB Berlin. ISBN: 9783921690543

Manzano, M. Lacumin, L., Vendrame, M., Cecchini, F., Comi \& G,Buiatti, s.(2011). Craft beer microflora identification before and after a cleaning process J. Inst. Brew. 117, 343-351, https://doi.org/10.1002/j.2050-0416.2011.tb00478.x Manzano, M., Giusto, C., Bartolomeoli, I., Buiatti, S. \& Comi, G., (2005) Microbiological analyses of dry and slurry yeasts for brewing. J. Inst. Brew. 111, 203-208. https://doi.org/10.1002/j.2050-0416.2005.tb00667.x

Menz, G., Aldred, P. \& Vriesekoop, F. (2009). Pathogens in beer. In: Elsevier /Academic Press (Ed.), Beer in Health and Disease Prevention. Victor Preedy, Amsterdamn; Boston, pp. 403-413. ISBN: 9780123738912

Menz, G., Andrighetto, C., Lombardi, A., Corich, V., Aldred, P., \& Vriesekoop, F. (2010a). Isolation, identification, and characterisation of beer-spoilage lactic acid bacteria from microbrewed beer from Victoria, Australia. J. Inst. Brew. 116, 14-22. https://doi.org/10.1111/1750-3841.13112

Menz, G., Vriesekoop, F., Zarei, M., Zhu, B. \& Aldred, P., (2010b). The growth and survivival of food-borne pathogens in sweet and fermenting brewers wort. $\begin{array}{llll}\text { Int. J. } & \text { Food } & \text { Microbiol. } & 140(1),\end{array}$ https://doi.org/10.1016/j.ijfoodmicro.2010.02.018

Michel M., Kopecká, J., Meier-Dörnberg, T., Zarnkow, M., Jacob, F. \& Hutzler M. (2016). Screening for new brewing yeasts in the non-Saccharomyces sector with Torulaspora delbrueckii as model. Yeast. 33, 129-144. https://doi.org/10.1002/yea.3146

Paradh, A. D., Mitchell, W. J \& Hill, A.E. (2011). Occurrence of Pectinatus and Megasphaera in the major UK breweries. J. Inst. Brew. 117, 498-506 https://doi.org/10.1002/j.2050-0416.2011.tb00497.x

Pham, T. Wimalasena, W. G. Box, K. Koivuranta, E., Storgårds, K. A. Smart \& B. R. Gibson (2011). Evaluation of ITS PCR and RFLP for Differentiation and Identification of Brewing Yeast and Brewery 'Wild' Yeast Contaminants. J. Inst. Brew. 117, 556-568. https://doi.org/10.1002/j.2050-0416.2011.tb00504.x

Rainbow, C., (1981). Beer spoilage organisms. In: Brewing Sciencie, J.R Pollock, Ed. Academic Press. London. ISBN: 125610025

Romano, D., Valdetara, F., Zambelli, P., Galafassi, S., Vitis, V., Molinari, F., Compagno, C., Foschino, R. \& Vigentini, I. (2017). Cloning the putative gene of vinyl phenol reductase of Dekkera bruxellensis in Saccharomyces cerevisiae. Food Microbiol. 63, 92-100. https://doi.org/10.1016/j.fm.2016.11.003

Sakamoto, K. \& Konings W.N. (2003). Beer spoilage bacteria and hop resistance. Int. J. Food Microbiol. 89, 105- 124. https://doi.org/10.1016/S0168 1605(03)00153-3

Serra Colomer, M., Funch, B. \& Forster, J. (2019). The raise of Brettanomyces yeast species for beer production. Curr. Opin. Biotech. 56, 30-35 https://doi.org/10.1016/j.copbio.2018.07.009 
Spitaels, F., Wieme, A.D., Janssens, M., Aerts, M. Anita Van Landschoot, Luc De Vuyst \& Vandamme, P. (2015). The microbial diversity of an industrially produced lambic beer shares members of a traditionally produced one and reveals a core microbiota for lambic beer fermentation. Food Microbiol. 49, 23-32 https://doi.org/10.1016/i.fm.2015.01.008

Suárez, J. \& Íñigo, L. (2004). Microbiología Enológica: Fundamentos de vinificación. Tercera Edición. Ediciones Mundi Prensa. España. ISBN 8484761843

Suzuki, K. (2011). 125th Anniversary Review: Microbiological instability of beer caused by spoilage bacteria. J. Inst. Brew. 117, 131-155 https://doi.org/10.1002/j.2050-0416.2011.tb00454.X

Suzuki, K., Asano, S., Lijima, K. \& Kitamoto, K. (2008). Sake and beer spoilage lactic acid bacteria. J. Inst. Brew. 114, 209-223.

The Brewers of Europe, 2018. Beer statistics 2018 edition. https://brewersofeurope.org/uploads/mycms-

files/documents/publications/2018/EU-beer-statistics-2018-web.pdf

Van Vuuren, H.J.J., Cosser, K. \& Prior, B.A., (1980). Influence of Enterobacter agglomerans on beer flavor. J. Inst. Brew. 86, 31-33 https://doi.org/10.1002/j.2050-0416.1980.tb03952.x

Vaughan A., O'Sullivan, T. \& Sinderen, D. (2005). Enhancing the microbiological stability of malt and beer. J. Inst. Brew. 111(4), 355-371. https://doi.org/10.1002/j.2050-0416.2005.tb00221.x

Vriesekoop, F., Krahl, M, Hucker, B \& Menz, G, (2013). Bacteria in brewing: The good, the bad and the ugly. J. Inst. Brew. 118, 335-345 https://doi.org/10.1002/jib.49 